\title{
Developing Web Based Modules of Animal Development Course
}

\author{
Fitri Hanifah Afnas ${ }^{1 *}$ Ramadhan Sumarmin ${ }^{2}$
}

\author{
${ }^{1}$ Magister Study Program of Biology Education, Universitas Negeri Padang, Padang, Indonesia \\ ${ }^{2}$ Biology Department Math and Natural Science Faculty, Universitas Negeri Padang, Padang, Indonesia \\ *Corresponding author. Email: fitrihanifah03@yahoo.co.id

\section{ABSTRACT}

As many as $78 \%$ of students, the subject of animal development is one of the complicated subjects to understand and requires a more detailed explanation in their understanding. However, biology students on 2019 at Padang University there are who still do not have a handbook in learning animal development, which can affect the results of the learning process of animal development course. Students assume that this courses will be easier to understand if it is assisted by using media in the form of video views, peer discussion, discussion with lecturers, and also repetition of courses discussion so that this lesson will be easier to understand and remember. This is supported by the advancement of technology, and we are required to always make positive developments. The absence of web-based media in animal development courses makes this one of the factors in web development to answer various existing problems. This website is used in the delivery of courses, both in the form of videos, and teaching material files, and also as a means of discussion for lecturers and students outside of learning hours. This website is also supported by two types of evaluation, namely quizzes and evaluation sheets. This website, the various facilities provided can help students and lecturers on understanding about animal development courses. So, a web based modules development is needed to answer various problems related on animal development courses

Keywords: Module Developing, Animal Development, e-learning, Web.

\section{INTRODUCTION}

Modules are independent learning packages that contain approved learning experiences and are designed to help students achieve learning goals. The main purpose of learning with modules is to improve the efficiency and effectiveness of learning in schools, both time, funds, facilities, and personnel to achieve goals optimally [1]. According to the [2] modules are printed teaching materials that are designed to be used independently by learning participants. Modules are also called media for independent learning because they have been equipped with instructions for self-study. Modules can be used for students in learning. In the module there will usually be learning material and also practice questions. However, biology students on 2019 at Padang University there are who still do not have a handbook in learning animal development, which can affect the results of the learning process of animal development course.

According to [3] to increase the competence of educators will be easier with the support of e-literacy. Educators can use e-literacy to find various information needed. Information obtained from the internet is then processed, analyzed so that new information is created. In addition, the use of e-literacy will add to the knowledge and insights of teachers welcoming the Industrial Revolution 4.0 era. Improving the quality of education in higher education in practice requires learning media in the hope of facilitating lecturers in delivering lecture material and making students easier in understanding learning. Improving the quality of education is related to the Industrial Revolution Era 4.0.
The Industrial Revolution Era 4.0, which emphasized digital economy, artificial intelligence, big data, and robotic, demanded that the education world construct creativity, critical thinking, technological mastery, and digital literacy abilities [3]. A teacher is required to be able to utilize information technology that is very quickly influenced by the factors of globalization. Nowadays, information and communication technology is developing rapidly with various forms and interests that can be widespread throughout the world. Therefore globalization cannot be avoided, especially in the field of education [4]. Because an educator needs to be equipped with innovative learning, open to science and technology and proactive, one of the learning systems that develops and can be utilized is e-learning. One thing that cannot be separated from elearning is the role of the internet. According to Soekartawi on[5], stated that the internet is basically a collection of information available on a computer that can be accessed because of the network available on that computer. Therefore, e-learning can be implemented because of internet services. Even e-learning is often referred to as an online course because its application utilizes internet services. E-learning can be used to support teaching and learning activities, in the eyes of animal development. Animal development material is one of the lecture materials at UNP which is quite complicated to understand. This is known from the results of observations, which as much as $58 \%$ of students find it difficult to understand this learning from books, and $65 \%$ of students still experience difficulties in understanding through lecturer teaching methods. So elearning can help students in their initial understanding before face-to-face meetings with lecturers in class, and can 
also be useful as a media that helps in repetition of learning the lessonwhen they cannot attend. E-learning can also be a discussion media between students and also between students and lecturers. This e-learning can be kind of web. Web can be interpreted as a various kind of pages that display text file information, picture, animated, sound, video, and a combination of all, both static and dynamic that form a series of interrelated buildings where each is connected with networks are very efficient compared to conventional learning [6]. So that on using this website can be very helpful in the learning process because it contains supporting content as mentioned. Using web learning in Biology learning process, it is expected to be useful for both lecturers and students, because the learning web can be accessed directly by students and in on-line mode. Time to learn the lesson becomes more efficient and students can learn the lesson even they can't present on classroom lesson. The application of biology learning web, would greatly assist lecturers and students in delivering lesson in the teaching and learning process. When it easier to deliver on lesson that requires clarity of images and visuals that are interesting to watch out for and its easy use both operationally and when an educator cannot be present in class but students can learn independently. Without the anxiety of missing lesson on students who cannot attend classroom, because they can access this lesson independently that can help the clarity on study.

Web-based modules are a combination on use between modules and the web. The web will contain features that should be present in modules with the addition of features that imposible be reached on kind of bookmedia, such as videos and other moving animations. So the web will contain learning with kind of videos, evaluations, online quizzes, and discussion rooms. In addition to the learning material that will be taken, the web will contain the latest information about the world of biology. So students should be able to develop their insights and create an interest in learning. Students can also access the web before study in classroom as a basis for initial knowledge before entering class.

\section{CONCLUSION}

The web based modules development is needed to answer various problems related on animal development courses

\section{REFERENCES}

[1] Mulyasa, E. 2003. Konsep, Karakteristik, Implementasi, dan Inovasi Kurikulum Berbasis Kompetensi. Bandung: PT Remaja Rosdakarya

[2] Depdiknas. 2008. Pengembangan Bahan Ajar. Jakarta: Depdiknas.

[3] Salim, Kalbin. 2015. Pengaruh Globalisasi terhadap Dunia Pendidikan. Malaisya. Universitas Teknologi Malaisya
Based on the background presented, innovation is needed in the development of Web-Based Modules on Animal Development Courses for students of Padang State University.

\section{MATERIALS AND METHODS}

Analysis of problems and needs with descriptive methods, the collection of information about problems in the process of learning activities on animal development materials and the need to develop webbased modules as a medium that can help in the learning process. Data collection by means of a questionnaire that has been provided by researchers. The results of problem and needs analysis can be used for consideration in planning and developing webbased modules that are practical for lecturers and students.

\section{RESULT AND DISCUSSION}

The results of the analysis of the problems and needs of semester III UNP biology students from the questionnaire showed that not all students have a learning handbook. Students claimed that they liked animal development material, but $78 \%$ of them found it difficult to understand animal development courses. More than $50 \%$ of students have no prior knowledge when entering class. This makes students want an interesting media and can help them in understanding animal development material. Almost all students support the development of this web-based module, and they have no difficulty in using the internet to support the continued use of webbased modules on animal development course.

[4] Wahyuni, Dinar. 2018. Peningkatan Kompetensi Guru Menuju Era Revolusi Industri 4.0. Pusat Penelitian Badan Keahlian DPR RI. Vol. X, No. 24/II/Puslit.Jakarta Pusat

[5] Darmawan, Deni. 2014. Pengembangan ELearning: Teori dan Desain. Bandung: PT Remaja Rosdakarya

[6] Mundiyakin, Ika dkk. 2012. Pengembangan Pembelajaran Sistem dalam Kehidupan Tumbuhan Berbasis WEB dengan Visualisasi dan Simulasi. Unnes Journal Of Biology Education, Vol.1, No.3

[7] Arbi, Y R., Sunarnin R., Putri D H. 2018. Development Module Oriented Science Technology Society Indue Science Literacy Assessment for 7thGrade Junior High School Students in 2nd -Semester. IOP Conf. Series: Materials Science and Engineering $335 \quad$ (2018) 012089 doi:10.1088/1757$899 X / 335 / 1 / 012089$ 